\title{
Research on the operation of cultural capital in regional economy Take Xijiang in Guizhou as an example
}

\author{
Yi Cen ${ }^{1}$ \\ ${ }^{1}$ College of Tourism and Aviation Services Guizhou Minzu University Guiyang, Guizhou, China
}

\begin{abstract}
In the process of globalization, the integration of world tourism is becoming more and more obvious. With the rapid development of China's tourism industry, Tourism in many provinces and cities has become a pillar industry or key industry, The various risks it faces are also gradually highlighted. Driven by regional economy, the capitalization operation of national culture is considered to be an effective way to protect national culture and develop economy in ethnic areas. However, national culture has brought many social problems in the process of concrete operation. This paper discusses the realistic dilemma of cultural capitalization in the tourism development of Miao villages in Xijiang, This paper points out that only by clarifying the relationship between the stakeholders in the operation of cultural capital and further clarifying the marketing strategy of cultural capital operation can we ensure the sustainable development of national culture capitalization.
\end{abstract}

\section{Introduction}

With the development of world economy, cultural tourism has become a new way of mass life. With the significant deepening of economic globalization, the acceleration of regional integration, and the interdependence, competition and co-existence of products, the global tourism industry is becoming a distinct theme. In recent years, the capitalized operation of national culture with the main purpose of "carrying forward national culture and developing national economy" is flourishing in some areas where ethnic minorities live in compact communities, and it is considered as an effective way to develop characteristic economy. In a broader sense, the capitalization of national culture has promoted the development of local economy, improved the material supply and information exchange in national areas, and thus created more favorable material conditions for the development of national culture.

\section{The definition of "tourism and cultural capital operation"}

The concept of cultural capital operation is specific to tourism, which can be understood in three forms. Namely, tourism cultural ability, tourism cultural products, tourism cultural system. Tourism cultural ability is based on personal quality internalized, based on personal development and practical activities, and its accumulation is carried out in specific forms such as culture, education and cultivation. Tourism cultural products are a unique cultural products. It is the unity of tourism cultural ability and economic capital, landscape is its form of existence.
Tourism cultural products contain certain value, which is revealed by tourists' tourism cultural ability in the process of use. Referring to the understanding way of the new institutional economics, the tourism cultural system is the result of many games of social interaction, and it is a kind of secret system, which mainly USES the media as the tool and mutual flap-up as the means to establish the most secret and deepest institutions-the cultural norms and beliefs of tourism culture.

In view of the above concepts, we can understand the "tourism culture capital operation", is in the government, tourism enterprises, operating under the guidance of the related subjects, tangible or intangible assets related to tourism to organically integrate, blend in culture in the tourism products, make cultural tourism products through the carrier, eventually forming a complete, subject of the concept of tourism culture, its purpose is to realize the value of tourism culture, the growth of benefits.

\section{Basic information of Xijiang}

Xijiang is located in the north of Leishan County, Southeast Guizhou Province, 37 kilometers from the county seat and 36 kilometers from Kaili. The village now has more than 1,300 households and more than 5,000 people, of which the Miao nationality accounts for $99.5 \%$. It is the largest ancient Miao village in China and has been listed as a preselected site of World Cultural Heritage by the United Nations. Xijiang is rich in national culture and has a long national history. Miao embroidery, miao silver jewelry forging, Miao ancient songs and stilted building construction skills have been included in the first batch of national intangible cultural heritage list by the State Council. "See Xijiang and know the Miao village in the 
world" is widely spread in the outside world, and the attraction of Xijiang as a rural tourism destination to experience Miao customs in China has begun to appear. The distribution of village tourism resources is shown in the figure:

Table1.

\begin{tabular}{|c|c|c|}
\hline \multirow{2}{*}{$\begin{array}{c}\text { Name of the } \\
\text { scenic spot }\end{array}$} & \multicolumn{2}{|c|}{ Tourism resources } \\
\cline { 2 - 3 } & Resource characteristics & Product categories \\
\hline \multirow{2}{*}{$\begin{array}{c}\text { Miao Village } \\
\text { in Xijiang }\end{array}$} & $\begin{array}{c}\text { The perfect combination } \\
\text { of culture "living fossil", } \\
\text { "Stilted building", rich } \\
\text { and colorful national } \\
\text { festivals, unique national } \\
\text { costumes }\end{array}$ & $\begin{array}{c}\text { Rural ecological tour, } \\
\text { rural vacation tour, } \\
\text { ethnic customs tour, } \\
\text { festival tourism }\end{array}$ \\
\hline
\end{tabular}

\subsection{Cultural resources of Miao Village in Xijiang}

In terms of resource types, Miao Village in Xijiang takes residential building community and ethnic culture as its main tourist attractions. The unique Miao architecture "stilted building", strong ethnic customs, exquisite ethnic craft and rich local specialties of Miao Village make its resource types focus on enjoying the primitive ethnic culture of miao compatriots. In terms of resource product development, the current key development projects include: appreciation of ethnic minority residential buildings, rural ecological tour, rural vacation tour, ethnic customs tour, ethnic cuisine and farming culture experience, festival tourism.

\subsection{The development characteristics of Miao Village in Xijiang}

Miao Village adopts the operation mode of "governmentled and mass participation". The advantage of this operation mode is to construct the scenic spot infrastructure under the planning of the government to provide tourists with cultural appreciation and experience. The villagers, under the guidance of the government and the promotion, operate independently to provide tourists with catering reception, accommodation reception, transportation service and management, production and sales of native products, and production of characteristic crafts.

\section{Utilization of relevant capital}

\subsection{Cultural capital -- the aspect held by villagers}

The application of cultural capital in Xijiang is mainly reflected in the villagers' ownership of stilted buildings, festival culture, costume culture and old village system. Through the investigation, the author learned that since 2007, Xijiang Miao Village Museum and the town government jointly carried out the pilot work of cultural heritage protection rating subsidy in Xijiang to encourage the construction of family museums. Miao Village Hall and the town government registered the articles with various ethnic characteristics owned by farmers, including stilted buildings of miao nationality, communication tools, production tools, daily life tools, costumes and ornaments, life technology machines, festival props and Musical Instruments, religious implements and funeral articles. Set up to thousands of nearby villagers representatives, museum staff, village cadres, xijiang culture experts, composed of representatives of national folk arts and crafts "xijiang of miao cultural heritage protection farmers rating evaluation committee", committee member of farmers on-site evaluation, comprehensive determine the level of peasant household and office work leading group for examination, verification and approval. Farmers who win the title of "family Museum" will be given corresponding bonuses and household appliances according to their level. For this reason, the participation enthusiasm of local residents is high. They are constantly adding various kinds of cultural heritage in their homes, and making labels and instructions to make family museums more standardized. With the benefits and equal opportunities for all households, farmers have established a good sense of competition, and the villagers blurt out "cultural heritage protection", which also indicates that the concept of "cultural heritage" has been rooted in the hearts of Miao villagers.

\subsection{Social capital -- Government management}

The development of Miao Village in Xijiang as a tourist village has basically been based on the development model of "government + farmers", that is, the government is responsible for planning, publicity and promotion, investment and construction, and farmers operate independently. many contradictions and problems are also increasingly apparent, and increasingly prominent. For this reason, Xijiang Scenic Area management Committee and scenic area management office are set up under the county Party Committee to coordinate the scenic area management and other institutions, and the contradictions existing in the development of tourism activities are coordinated by combining the institutional form of Miao village Xijiang, namely the villagers committee and the "zhai lao system". At present, this management method has achieved good results. In Xijiang, the local government has done a good job of mass work in accordance with the principle of "government leading and mass participation". It is to start from the organ department first, build national atmosphere hard, give play to the leading role of cadre worker. It is stipulated that all cadres and staff members of Xijiang Village Committee wear Miao clothes on holidays and ethnic festivals. The government has launched an activity of "learning a miao nationality's skill" among cadres and workers, requiring every cadre to learn to sing one or two Miao songs to create a good environment for folk tourism.

\subsection{Economic capital -- tourism enterprises}

In cooperation with travel agencies, many travel agencies in leishan county tourism bureau and province signed a cooperation agreement, in the survey, the travel agency, have said, head of xijiang biggest competitive advantage lies in its "uniqueness", now it's "hardware" and 
"software" has high standard reception conditions, xijiang will attract visitors from all over the world. They have targeted at the business opportunities of Xijiang, ready to recommend "xijiang", "Nanhua", "Zhaoxing"and other tourist routes to travel agencies outside the province, believing that Xijiang Miao Village will set off a peak of rural tourism in Guizhou. With the development of tourism, at present Xijiang Scenic Area Administration has signed cooperation agreements with more than 50 travel agencies in and outside the province, such as Shanghai Chunqiu travel agency and Guangzhou Guangzhi travel agency, Through attracting colleges and universities and social organizations to set up practice bases and collection bases, Xijiang scenic area has established extensive cooperative relations and broadened the tourist source market.

\section{5 the strategic choice of tourism cultural capital operation}

\subsection{The government should not "offside"}

From the perspective of the country as a whole, the status of national culture has been marginalized. As a subculture, the status of national culture is obviously lower than that of mainstream culture. However, with the development of tourism economy, the more national, the more international. When the government helps the minority areas to get rid of poverty and become rich, it takes tourism as the primary poverty alleviation policy. The development of tourism drives the local economy, and tourism also becomes the main play in the development of economy. In the operation of regional economy, the ideal model of government should be the unity of coordinator, investor and server. The existence of market failure requires the intervention of the government. Under this premise, the government should carry out "investment control" in the development of tourism, standardize the short-sighted behavior of tourism enterprises that excessively pursue economic interests and ignore the protection of cultural resources, and exert influence indirectly through macro-control of the market to ensure the stability and long-term stability of the market and achieve the guiding function of culture.

\subsection{Tourism enterprises should not be "absent"}

The relationship between tourism enterprises and local villagers is irrelevant before development. Villages in rural tourism, after being certified to have unique tourism resources, are regarded by enterprises as objects that can bring tourism economic profits. Companies focus on efficiency, but only through the development and sale of each other's cultural resources. This requires tourism enterprises to pursue economic interests while pursuing cultural capital, abandon the previous cultural functions and blindly pursue economic benefits. Instead, they should consider from a long-term and lasting perspective, and give consideration to the development and protection of cultural resources while pursuing economic interests.
Because of the absence of villagers and their cultural heritage, the work of tourism operators cannot be carried out, and those cultural resources with great development value, tourism developers need to invest in the development and protection. From the point of view of market economy, the government funding is limited, can't do everything, government investment mainly builds the external conditions of the scenic spot, on the depth development of scenic spots, needs the enterprise participation, the tourism enterprises to the specific business projects investment and construction, product development is the main operation, only the enterprise mastered the operation experience and methods of tourism industry, development mode, understand the laws of the tourism market operation, to achieve greater profits and pay to maintain appropriate business operating funds, achieve sustainable development. From the perspective of social and cultural resources, tourism enterprises should have the operation ability of economic benefits and the awareness of environmental protection. Tourism enterprises are not only the service providers of tourists, but also their educators. In order to achieve these goals, tourism enterprises can gain advantages in cost and brand through positive incentives, and standardize their operation and management through mandatory requirements.

\subsection{Villagers cannot "discard"}

In the process of tourism development, villagers get economic income by participating in the tourism activities of the community, at the same time, villagers adjust their identity evaluation through the involvement of tourism economic activities. In the process of carrying out tourism activities, villagers increasingly understand the attraction of their own national culture. They read their satisfaction and pride from the envious eyes of the surrounding villages and realize that their status is improving. However, with the continuous increase of tourism income, cultural elites in the village begin to show a sense of superiority, while ordinary villagers gradually turn the pursuit of cultural interests into the pursuit of economic interests while looking for cultural resources that can exchange economic values. Villagers began to discard the authenticity of culture unintentionally, and the phenomenon of cultural commercialization began to guide villagers to transform from "digging" and "reviving" to "discarding" culture. In order to make local communities become the core of rural tourism development, it is necessary to integrate them into the decision-making, management and benefit distribution system of rural tourism, so as to realize the empowerment of economic, political, psychological and social aspects -- to obtain lasting and fair economic benefits. The interests and needs of most people are best represented; Increased self-esteem of community members as a result of external recognition of their cultural identity and values, natural resources and traditional knowledge, and increased the status of those members of society (such as women) who traditionally had a lower social status; Maintain the balance of local communities and enhance community cohesion. 


\section{6 summarize}

In the above premise, in the development of rural tourism, to meet the government, tourism enterprises, and the villagers of harmonious win-win situation, the government will be the role of transformation in the past, from the elites to coordinator, gradually help tourism enterprises management crisis, the tourism enterprises to deal with the problem through market means, play their part, fill the blank of the market. Tourism enterprises should actively cooperate with and support of the government of the relevant development work, to do the "market as stage, the government for the director, the corporations' development mode to develop themselves, actively involved in the government organization of all kinds of festival activities, the previous development and protection of the cultural turn, must be the work of the government's consciousness to participate in the protection work of culture, and community residents to fully participate in the development of tourism activities, through the reasonable benefit distribution mechanism, improve their enthusiasm to participate in rural tourism development and protection of the rural tourism landscape of self-consciousness, In order to improve the attraction of rural tourism and maintain the lasting vitality of rural tourism. The integration of the three kinds of capital can elevate the market operation of cultural industry to the scene of market and cultural inheritance.

\section{References}

1. L. Yang. Research on Connotation Construction of Community Culture Governance[J]. Journal of Shanxi Datong University, 2019(03): 23-24. (in Chinese)

2. J. X. Sun. Tourism Development and the Construction of Post-local Community[J]. Journal of Northern University for Nationalities, 2019(03): 101-108. (in Chinese)

3. N. Shi. Research on the Cultivation of Community Social Capital in Village Resettled Communities: Based on the Survey of P Community in Shenzhen[D]. Jiangxi University of Finance and Economics, 2018. (in Chinese)

4. Mihuandayani and Ema Utami. Design Concept Integration Tax Payment System with Implementing Financial Technology[J]. International Journal of Information Engineering and Electronic Business, 2018, 9(8): 15-22.

5. Tamir Anteneh Alemu, Alemu Kumilachew Tegegne and Adane Nega Tarekegn. Recommender System in Tourism Using Case based Reasoning Approach[J]. International Journal of Information Engineering and Electronic Business, 2017, 9(8): 34-43.

6. Cao Dan. On the impact of sharing economy on tourism development and its countermeasures [J]. Journal of sichuan normal university (social science edition),2017(01).

7. Jia chao. Study on the impact of tourism development

on rural families -- a case study of $\mathrm{K}$ village in taiyuan [J]. Shanxi youth, 2016, (9) :157-158. 